\title{
Impact of external carbon dose on the removal of micropollutants using methanol and ethanol in post-denitrifying Moving Bed Biofilm Reactors
}

Torresi, Elena; Escolà Casas, Mònica; Polesel, Fabio; Plósz, Benedek G.; Christensson, Magnus; Bester, Kai

Published in:

Water Research

Link to article, DOI:

10.1016/j.watres.2016.10.068

Publication date:

2017

Document Version

Peer reviewed version

Link back to DTU Orbit

Citation (APA):

Torresi, E., Escolà Casas, M., Polesel, F., Plósz, B. G., Christensson, M., \& Bester, K. (2017). Impact of external carbon dose on the removal of micropollutants using methanol and ethanol in post-denitrifying Moving Bed Biofilm Reactors. Water Research, 108, 95-105. https://doi.org/10.1016/j.watres.2016.10.068

\section{General rights}

Copyright and moral rights for the publications made accessible in the public portal are retained by the authors and/or other copyright owners and it is a condition of accessing publications that users recognise and abide by the legal requirements associated with these rights.

- Users may download and print one copy of any publication from the public portal for the purpose of private study or research.

- You may not further distribute the material or use it for any profit-making activity or commercial gain

- You may freely distribute the URL identifying the publication in the public portal 


\section{Impact of external carbon dose on the removal of micropollutants using} methanol and ethanol in post-denitrifying Moving Bed Biofilm Reactors

3

4

5

6

7

8

9

10

11

12

13

15

16 17

18 (8)

Elena Torresi ${ }^{\dagger 1,2}$, Mònica Escolà Casas ${ }^{\dagger}$, Fabio Polesel² ${ }^{2}$, Benedek G. Plósz ${ }^{2 *}$, Magnus

$$
\text { Christensson }^{1 *} \text {, Kai Bester }{ }^{3 *}
$$

${ }^{\dagger}$ Joint first authors; *Corresponding authors: kb@dmu.dk; magnus.christensson@anoxkaldnes.com;

beep@env.dtu.dk;

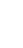

\footnotetext{
${ }^{1}$ Veolia Water Technologies AnoxKaldnes, Klosterängsvägen 11A, SE-226 47 Lund, Sweden

${ }^{2}$ Department of Environmental Engineering, Technical University of Denmark, Bygningstorvet B115, 2800 Kgs. Lyngby, Denmark ${ }^{3}$ Department of Environmental Science, Århus University, Frederiksborgvej 399, 4000 Roskilde, Denmark
}

Keywords: pharmaceuticals; MBBR; carbon source; biofilms; wastewater; denitrification 


\section{Abstract}

Addition of external carbon sources to post-denitrification systems is frequently used in wastewater treatment plants to enhance nitrate removal. However, little is known about the fate of micropollutants in post-denitrification systems and the influence of external carbon dosing on their removal. In this study, we assessed the effects of two different types and availability of commonly used carbon sources — methanol and ethanol— on the removal of micropollutants. Two laboratoryscale moving bed biofilm reactors (MBBRs), containing AnoxKaldnes K1 carriers with acclimated biofilm from full-scale systems, were operated in continuous-flow using wastewater dosed with methanol and ethanol. Batch experiments with 22 spiked pharmaceuticals were performed to assess removal kinetics. Acetyl-sulfadiazine, atenolol, citalopram, propranolol and trimethoprim were easily biotransformed in both MBBRs (biotransformations rate constants $\mathrm{k}_{\text {bio }}$ between 1.2 and 12.9 $\mathrm{L}_{\text {biomass }}{ }^{-1} \mathrm{~d}^{-1}$ ), 13 compounds were moderately biotransformed (rate constants between 0.2 and $2 \mathrm{~L}$ g $_{\text {biomass }}{ }^{-1} \mathrm{~d}^{-1}$ ) and 4 compounds were recalcitrant. The methanol-dosed MBBR showed higher $\mathrm{k}_{\text {bio }}$ (e.g., 1.5 to 2.5-fold) than in the ethanol-dosed MBBR for 9 out of the 22 studied compounds, equal $\mathrm{k}_{\text {bio }}$ for 10 compounds, while 3 compounds (i.e., targeted sulfonamides) were biotransformed faster in the ethanol-dosed MBBR. While biotransformation of most of the targeted compounds followed first-order kinetics, removal of venlafaxine, carbamazepine, sulfamethoxazole and sulfamethizole could be described with a cometabolic model. Analyses of the microbial composition in the biofilms using 16S rRNA amplicon sequencing revealed that the methanol-dosed MBBR contained higher microbial richness than the one dosed with ethanol, suggesting that improved biotransformation of targeted compounds could be associated with higher microbial richness. During continuous-flow operation, at conditions representative of full-scale denitrification systems (hydraulic residence time $=2 \mathrm{~h}$ ), the removal efficiencies of micropollutants were below $35 \%$ in both MBBRs, with the exception of atenolol and trimethoprim (>80\%). Overall, this study 
43 demonstrated that MBBRs used for post-denitrification could be optimized to enhance the 44 biotransformation of a number of micropollutants by accounting for optimal carbon sources and 45 extended residence time. 


\section{Introduction}

Currently used biological processes in conventional wastewater treatment plants (WWTPs) are designed to remove organic carbon and nutrients (nitrogen and phosphorus). As organic micropollutants are gaining attention due to the associated environmental risks (Daughton and Ternes, 1999; Plósz et al., 2013), the optimization of biological processes for removal of micropollutants during wastewater treatment is crucial (Joss et al., 2008). Micropollutants (e.g., pharmaceuticals and personal care products) are generally recognized as non-growth substrates (secondary substrates), as they are present in wastewater in too low concentrations (ng $\mathrm{L}^{-1}$ to $\mu \mathrm{g} \mathrm{L}^{-1}$ ) to support biomass growth (Fischer and Majewsky, 2014; Rittmann, 1992). Therefore, biological transformation of micropollutants is mainly the result of cometabolic mechanisms, whereby the removal of non-growth substrates (micropollutants) requires the presence of primary substrates (i.e., COD, nutrients) to support biomass growth (Criddle, 1993; Rittmann, 1992). In cometabolism, the biotransformation of micropollutant is typically catalyzed by non-specific enzymes (e.g., mono- or di-oxygenases, $\mathrm{N}$-acetyltransferases, hydrolases) or by cofactors produced during the microbial conversion of the primary substrate (Criddle, 1993; Fischer and Majewsky, 2014). Nevertheless, the interaction between primary substrate and micropollutants is complex and not completely understood. In fact, the presence of primary substrate has been reported to either enhance the removal of micropollutants, e.g., by regenerating reductants such as $\mathrm{NAD}(\mathrm{P}) \mathrm{H}$ under aerobic conditions (Alvarez-Cohen and Speitel, 2001; Liu et al., 2015), or decrease it, due to competitive enzyme inhibition (Fischer and Majewsky, 2014; Plósz et al., 2010).

Recent studies have proposed biofilm systems, e.g., moving bed biofilm reactors (MBBR), as a promising alternative to activated sludge systems (CAS) with respect to the attenuation of micropollutants (Escolà Casas et al., 2015a; Falås et al., 2012; Hapeshi et al., 2013; Torresi et al., 
2016). In general, most of the studies concerning the removal of micropollutants during biological wastewater treatment have focused on aerobic systems, whereas only little information is available for anoxic denitrifying conditions: Plósz et al., 2010; Su et al., 2015; Falås et al. 2013, Suárez et al., 2010. While pharmaceuticals such as diclofenac, metoprolol, erythromycin and roxithromycin were found to be transformed mainly under aerobic conditions in activated sludge using synthetic wastewater (Suárez et al., 2010) and in hybrid biofilm-activated sludge processes (Falås et al., 2013), some of the investigated chemicals had similar (i.e., bezafibrate, atenolol, clarithromycin and $\mathrm{N}^{4}$-acetylsulfamethoxazole) or higher (i.e., levetiracetam) biotransformation under anoxic conditions than under aerobic ones (Falås et al., 2013). Hence, anoxic biological processes in conventional WWTPs should be considered as a potential step to optimize removal of micropollutants.

The type of carbon source is known to have a strong impact on the structure of denitrifying microbial communities and thus on denitrification efficiency (Baytshtok et al., 2009; Hagman et al., 2007; Lu et al., 2014). This has specific relevance to post-denitrification reactors in full-scale WWTPs, where nitrate removal is achieved by dosing external carbon sources such as methanol and ethanol (Louzeiro et al, 2002; Santos et al., 2001). Methanol and ethanol are metabolized by denitrifying bacteria through different pathways. Methanol undergoes the metabolic reaction of single-carbon compounds, which is exclusive to methylotrophs because of their unique key enzyme (methanol dehydrogenase) that catalyzes the oxidization of methanol to formaldehyde (Anthony et al., 1982, 2011). Instead, ethanol is easily converted by bacterial cells to Acetyl-CoA before entering the glyoxylate cycle (Anthony et al., 2011). Thus, microbial communities in postdenitrifying systems using either of these carbon sources may be fundamentally different and potentially exhibit a different biodiversity and functionality with more or less microbial specialists able to biotransform organic micropollutants. Additionally, biodiversity in terms of species richness 
(the number of species) and evenness (the relative abundance of the species) (Wittebolle et al., 2009) was shown to positively associate with the biotransformation of a number of micropollutants in aerobic activated sludge (Johnson et al., 2015; Stadler and Love, 2016) and nitrifying MBBRs (Torresi et al., 2016). Further investigation of the impact of biodiversity in different biological treatment systems seems thus required.

In this study, we evaluated the elimination of selected micropollutants (i.e., pharmaceuticals) in laboratory-scale post-denitrifying MBBRs dosed with methanol or ethanol. Biotransformation kinetics and removal efficiencies were assessed through targeted batch experiments and during continuous-flow MBBR operation, respectively. The objectives of our study were: (i) to investigate the impact of different types of external carbon sources (methanol and ethanol) for postdenitrification on micropollutant biotransformation; (ii) to assess the structure of the denitrifying microbial community of MBBR biofilms, following continuous dosing with either methanol or ethanol; and (iii) to evaluate the influence of organic substrate availability on the transformation of micropollutants and the related mechanisms, i.e. competitive inhibition and cometabolic enhancement.

\section{Materials and Methods}

\subsection{Description of the post-denitrifying systems}

Two Swedish WWTPs, i.e., Sjölunda and Klagshamn are currently dosing methanol or ethanol, respectively, as external carbon source in two-stage post-denitrification MBBRs. Thus, two laboratory-MBBRs were built to resemble such post-denitrification stages, using carriers (AnoxKaldnes K1) from the first post-denitrification tank of the respective WWTPs already adapted to methanol and ethanol dosing. The WWTPs are described in Section S1 of the SI (Supporting 
Information). Both laboratory-MBBRs (1 L) were operated in continuous feeding of the same wastewater, which was collected after the (aerobic) nitrification step (trickling filter) of Sjölunda WWTP (Lund, Sweden). Thus, during continuous-flow operation, only the indigenous nitrate and nitrite present in the wastewater (averaged concentration of 13 and $1.2 \mathrm{mg} \mathrm{L}^{-1}$ respectively) were used for denitrification. The filling rate of both reactors was $40 \%$, giving a surface of $0.2 \mathrm{~m}^{2}$. The amount of indigenous micropollutants in the reactor influents (consisting in the collected wastewater and feed containing carbon-source) was analyzed. Twelve compounds were quantified giving concentrations between $0.04 \mu \mathrm{g} \mathrm{L}^{-1}$ (trimethoprim) and $78 \mu \mathrm{g} \mathrm{L}^{-1}$ (iohexol). Complete details of these results are given in Table S6 (SI).

The reactors were continuously flushed with nitrogen gas and stirred for the mixing of the carriers and to strip eventual residual dissolved oxygen. Both reactors were kept at $15^{\circ} \mathrm{C}$ using a water bath. The feed wastewater was mixed and kept at $4{ }^{\circ} \mathrm{C}$ during the whole experiment. Phosphate was added to the feed to reach a concentration of $0.5 \mathrm{mg} \mathrm{L}^{-1}$ to ensure biofilm growth on the carriers. Micropollutant removal and denitrification rates in MBBRs were assessed in two main experiments: (i) batch conditions ( $24 \mathrm{~h})$ and (ii) continuous-flow operation (2 months). The carbon availability of ethanol and methanol into the two MBBRs was defined as the ratio between the influent loading of organic carbon $\left(\mathrm{COD}_{\text {added }}\right)$ and the native loading of nitrate $\left(\mathrm{NO}_{3}-\mathrm{N}_{\text {influent }}\right)$ in the wastewater samples. Optimum $\mathrm{COD}_{\text {added }} / \mathrm{NO}_{3}-\mathrm{N}_{\text {influent }}$ ratio $\left(\mathrm{gCOD} \mathrm{gN}^{-1}\right)$ for complete denitrification is typically around 4 (Metcalf \& Eddy, 2003).

\subsection{Analytical methods}

All the samples taken for analysis of conventional pollutants $\left(\mathrm{NH}_{4}{ }^{+}-\mathrm{N}, \mathrm{NO}_{3}{ }^{-}-\mathrm{N}, \mathrm{NO}_{2}{ }^{-}-\mathrm{N}\right.$, soluble $\mathrm{COD}$ and $\mathrm{PO}_{3}{ }^{4-}$ ) in batch and continuous experiments were filtered through $0.45 \mu \mathrm{m}$ glass fiber 
143 filters (Sartorius, Göttingen, Germany). Total COD and total nitrogen were analyzed on the 144 unfiltered sample. All samples were prepared in Hach Lange kits (LCK 303, LCK 339, LCK 341 145 and LCK 342) and analyzed in a Hach Lange DR2800 spectrophotometer. DO, pH and temperature 146 in the reactors were measured at each sampling occasion, using a Hach HQ40d multi DO probe and 147 a HANNA H1991001 pH-meter. The attached biomass concentrations were calculated from the 148 difference in weight of 3 dried carriers $\left(105{ }^{\circ} \mathrm{C}\right.$ for $>24 \mathrm{~h}$ ) before and after biofilm removal (in $2 \mathrm{M}$ $149 \mathrm{H}_{2} \mathrm{SO}_{4}$ ) with subsequent brushing (see Figure S2 for results), as previously considered (Escolà 150 Casas et al., 2015a; Falås et al., 2012; Torresi et al., 2016). Samples for micropollutants were frozen at $-20{ }^{\circ} \mathrm{C}$ prior analysis and analyzed via direct injection using HPLC-MS/MS as described in

152 Escolà Casas et al. (2015a). Information regarding sample preparation, HPLC, mass spectrometry data, LOD and LOQ of compounds are shown in Escolà Casas et al. (2015a) and in Section S2 (SI).

\subsection{Chemicals}

Twenty-two relevant micropollutants (i.e., pharmaceuticals) were selected for this study. Information regarding CAS numbers and chemical suppliers is found in the supplementary information in Escolà Casas et al. (2015b). The pharmaceuticals included: (i) four beta-blockers, i.e., atenolol, metoprolol, propranolol and sotalol; (ii) five X-ray contrast media, i.e., diatrizoic acid, iohexol, iopamidol, iopromide, iomeprol; (iii) three sulfonamides, i.e., sulfadiazine, sulfamethizole and sulfamethoxazole and the metabolite acetyl-sulfadiazine; (iv) three analgesics, i.e., phenazone, diclofenac and ibuprofen; (v) three anti-epileptics/anti-depressants, i.e., carbamazepine, venlafaxine 163 and citalopram; (vi) four antibiotics, i.e., erythromycin, clarithromycin, trimethoprim and 164 roxithromycin. 


\subsection{Batch experiment}

168 To investigate how the type of dosed carbon source influences the removal of micropollutants in post-denitrifying MBBR, batch experiments were performed in the same reactors used during continuous-flow operation. These experiments were conducted after 3.5 months of continuous-flow operation of the two systems. During the batch experiments, a $\mathrm{COD}_{\text {added }} / \mathrm{NO}_{3}-\mathrm{N}_{\text {influent }}$ ratio of 3.4 for both reactors was adopted to obtain excess concentration of nitrate. Anoxic conditions were maintained by flushing the reactors with nitrogen gas during the experiment. The feed used for the batch consisted of the same wastewater used in continuous operation spiked with $239 \pm 2 \mathrm{mg}$ $\mathrm{COD} \mathrm{L}^{-1}$ of methanol for the methanol-dosed reactor and the same amount of ethanol for the ethanol-dosed reactor, $70 \pm 3 \mathrm{mg} \mathrm{NO}_{3}-\mathrm{N} \mathrm{L}^{-1}$ in form of sodium nitrate and 22 micropollutants with an initial nominal concentration of $2 \mu \mathrm{g} \mathrm{L} \mathrm{L}^{-1}$. The micropollutants were added from a stock solution 178 (40 $\mathrm{mg} \mathrm{L}^{-1}$ in methanol). To minimize the increase of COD concentration in the batch feed due to the methanol from the stock solution, the micropollutant solution was first spiked into an empty glass beaker and the methanol was let to evaporate for approximately 1 hour. Afterwards, the feed was added to the beaker containing the micropollutants and mixed to re-dissolve the micropollutants. The batch experiment lasted 24 hours and samples for conventional and micropollutants analysis were taken at regular intervals. To keep the biomass concentration constant during the experiment, three carriers were withdrawn from the reactors each time a sample was taken for analysis. The $\mathrm{pH}$ value in both reactors was continuously measured and adjusted to 7.5 using $1 \mathrm{M} \mathrm{HCl}$. The temperature was kept constant at $15^{\circ} \mathrm{C}$.

\subsubsection{Denitrification during batch experiment}

Denitrification rates normalized on surface area of reactors $\mathrm{r}_{\mathrm{NO} 3,2-\mathrm{N}}\left(\mathrm{gNO}_{3,2}-\mathrm{N} \mathrm{m}^{-2} \mathrm{~d}^{-1}\right)$ and specific 
through linear regression using $\mathrm{NO}_{3}{ }^{-}-\mathrm{N}$ and $\mathrm{NO}_{2}{ }^{-}-\mathrm{N}$ measurements during batch experiment. An accumulation of nitrite in the systems was noticed $\left(\sim 6 \mathrm{mg} \mathrm{L}^{-1}\right)$, therefore $\mathrm{NO}_{3,2}-\mathrm{N}$ utilization curves accounting also for $\mathrm{NO}_{2}{ }^{-}-\mathrm{N}$ concentration were derived accordingly to Sözen et al. (1998).

A two step-denitrification activated sludge model (ASM) was used to describe up-take of primary substrates (i.e., readily soluble biodegradable $\operatorname{COD}\left(\mathrm{S}_{\mathrm{S}}\right)$, soluble nitrate $\left(\mathrm{S}_{\mathrm{NO} 3}\right)$ and nitrite $\left.\left(\mathrm{S}_{\mathrm{NO} 2}\right)\right)$ which was extended with the Activated Sludge Model for Xenobiotics ASM-X (Plósz et al., 2012; Polesel et al., 2016) to determine micropollutant biotransformation rates (Table 1). Readily soluble biodegradable $\operatorname{COD}\left(\mathrm{S}_{\mathrm{S}}\right)$ was determined as the difference between soluble COD (sCOD)measured during the experiments — and soluble inert COD $\left(\mathrm{S}_{\mathrm{I}}\right)$ — calculated according to Roeleveld and Van Loosdrecht (2002). The ASM for denitrification was adapted from Pan et al. (2015) and included two process rate equations with reduction of nitrate to nitrite (R1) and nitrite to nitrogen (R2) (Table 1). Parameters that could not be identified through model calibration to experimental results (maximum specific growth rates $\mu_{\mathrm{H}}$, affinity constants for substrate $-\mathrm{K}_{\mathrm{S} 1}$ and $\mathrm{K}_{\mathrm{S} 2}$-and for nitrogen species- $K_{N O 3}^{H B}$ and $K_{N O 2}^{H B}-$ ) were adopted from literature (Hiatt and Grady, 2008). Parameters that are known to be sensitive to the experimental data (i.e., heterotrophic yields $\mathrm{Y}_{\mathrm{H}}$, anoxic growth factors for the process 1 and $2, \eta_{\mathrm{g} 1}$ and $\eta_{\mathrm{g} 2}$ ) were calibrated. Definition of the components and model calibration are presented in Section S3 and Table S1 (SI). The model was implemented in AQUASIM 2.1d (Reichert et al., 1994) and the parameters were estimated using the secant method embedded.

\subsubsection{Micropollutants removal kinetics during batch experiment}

Model structures to assess biotransformation rate of micropollutants were identified using the ASM$\mathrm{X}$ as modelling framework (Polesel et al., 2016; Plósz et al., 2010, 2012, 2013). The framework 
used in this study is summarized in Table 1 and included processes such as parent compound retransformation (e.g., deconjugation of human metabolites) (1), biotransformation (2) and cometabolic biotransformation (in the presence and absence of organic growth substrate) (3). The effect of diffusion into biofilm on the removal of pharmaceuticals from bulk aqueous phase was lumped in the biotransformation rate constants, as previously considered by Falås et al. (2012, 2013), Escolá Casas et al. (2015a) and Hapeshi et al. (2013). The cometabolic process was modelled as proposed by Plósz et al. (2012), using pseudo-first order kinetics with respect to micropollutant concentration and estimating two biokinetics: (i) the cometabolic biotransformation rate constant $\mathrm{q}_{\mathrm{bio}}$ in the presence of the primary substrate and (ii) biotransformation rate constant $\mathrm{k}_{\text {bio }}$ in the absence of primary substrate. Accordingly, biotransformation kinetics of the cometabolic substrate (e.g., micropollutant) depend on the primary substrate concentration (e.g., organic matter micropollutants was considered negligible. 
238 Biotransformation constants $\mathrm{k}_{\text {bio }}$ (process 2, Table 1) were estimated from the measured data using 239 least-square optimization without weighting in GraphPad Prism 5.0. Parent compound 240 retransformation and cometabolism model (processes 1 and 3, Table 1) were implemented in 241 AQUASIM 2.1d (Reichert et al., 1994) and the parameters were estimated using the secant method 242 embedded.

243 Removal rate constants $\mathrm{k}\left(\mathrm{d}^{-1}\right)$ were also estimated to compare the performance of the two MBBR 244 systems, regardless of biomass concentration and sorption processes (Escolà Casas et al., 2015a,b). 245 For the chemicals following cometabolism model (and thus exhibiting two biokinetics), $\mathrm{k}$ was 246 calculated considering the estimated $\mathrm{q}_{\mathrm{bio}}$. Differences between biotransformation rate constants of 247 the two MBBRs were assessed by examining the overlap between standard deviations of the 248 estimated values (Cumming et al., 2007).

2.5 DNA extraction, PCR amplification, sequencing and bioinformatics analysis.

251 One carrier was collected from each MBBR before the batch experiment and stored in a sterilized 252 Eppendorf tube at $-20{ }^{\circ} \mathrm{C}$. Biomass was detached using a sterile brush (Gynobrush, Dutscher 253 Scientific, United Kingdom) using tap water and consequently centrifuged (10000 rpm for 5 254 minutes) to remove excess water. DNA extraction, PCR amplification (using 16S rRNA bacteria 255 gene primers) and Illumina sequencing were performed as described in Section S5 of the SI. 256 Taxonomic assignment and calculation of alpha diversity metrics (Shannon biodiversity and ACE 257 extrapolated richness) were performed in mothur using the RDP reference taxonomy. Additional 258 diversity indices were calculated according to Hill et al. (1973). Microbial evenness was estimated 259 as $\mathrm{H}_{1} / \mathrm{H}_{0}$ as described in Johnson et al. (2015). 


\subsection{Continuous-flow experiment}

262 The two MBBRs used for the present study were operated for over 4 months. The MBBRs were 263 kept with a $\mathrm{COD}_{\text {added }} / \mathrm{NO}_{3}-\mathrm{N}_{\text {influent }}$ ratio equal to 3 (close to the ratios used at the respective 264 WWTPs) for the first two weeks of operation. The fraction of inert COD was taken into account (by 265 subtracting it from the amount of available biodegradable COD) when planning experiments under 266 carbon limitation. A hydraulic retention time (HRT) of 2 hours was set similar to the HRT used at 267 the full-scale WWTPs. After two weeks of acclimatization, baseline carbon-dosage periods of $268 \mathrm{COD}_{\text {added }} / \mathrm{NO}_{3}-\mathrm{N}_{\text {influent }}$ were alternated with short carbon-dosage periods ( $\sim$ days) to avoid biomass 269 adaptation. Accordingly, concentrations of methanol and ethanol in the feed solutions were changed 270 to test $\mathrm{COD}_{\text {added }} / \mathrm{NO}_{3}-\mathrm{N}_{\text {influent }}$ ratios ranging from 1 to 5 , while keeping constant HRT. This test 271 phase lasted about 2 months. The $\mathrm{COD}_{\text {added }} / \mathrm{NO}_{3}-\mathrm{N}_{\text {influent }}$ ratios and the dates are reported in the 272 Table $\mathrm{S} 3(\mathrm{SI})$. The range of $\mathrm{COD}$ added $/ \mathrm{NO}_{3}-\mathrm{N}_{\text {influent }}$ ratios was chosen to assess carbon limiting 273 condition at low $\mathrm{COD}_{\text {added }} / \mathrm{NO}_{3}-\mathrm{N}_{\text {influent }}$ ratio and not far exceeding the stoichiometric $274 \mathrm{COD}_{\text {added }} / \mathrm{NO}_{3}-\mathrm{N}_{\text {influent }}$ ratio needed for complete denitrification. The denitrification rate $\mathrm{r}_{\mathrm{D}}\left(\mathrm{gN} \mathrm{d}^{-1}\right.$ $275 \mathrm{~m}^{-2}$ ) in continuous operation, was calculated for each carbon-dosage test by using the Equation S1 276 (Section S6, SI). Micropollutant removal efficiency ("measured removal" in Figure 4) was 277 calculated as difference between inlet and outlet concentrations. Micropollutant removal efficiency 278 during continuous operation ("predicted removal" in Figure 4) was predicted using removal rate 279 constant $\mathrm{k}\left(\mathrm{d}^{-1}\right)$ estimated during batch experiment according to Equation 1:

$$
\text { Removal }(\%)=\left(1-\left(\frac{1}{\left(1+k_{i} \cdot H R T\right)}\right)\right) \cdot 100 \quad \text { Equation } 1
$$




\section{Results and discussion}

\subsection{Batch experiment}

\subsubsection{Denitrification kinetics}

Denitrification rates $\left(\mathrm{r}_{\mathrm{NO} 3,2-\mathrm{N}}, \mathrm{k}_{\mathrm{NO}, 2-\mathrm{N}}\right)$ were derived through linear regression of measured $\mathrm{NO}_{3}{ }^{-} \mathrm{N}$ and $\mathrm{NO}_{2}{ }^{-} \mathrm{N}$ concentration during batch experiment (Figure S5, SI). The ethanol-dosed reactor presented a higher surface-normalized denitrification rate $\mathrm{r}_{\mathrm{NO}, 2-\mathrm{N}}($ Table 2$)$ than the methanol driven one, which is in agreement with previous studies (Santos et al., 2001; Christensson et al., 1994). This is likely due to the higher growth yield expected using ethanol thereby leading to higher biomass production per surface area in ethanol-dosed systems (Mokhayeri et al., 2009). On the other hand, denitrification rates $\left(\mathrm{k}_{\mathrm{NO}, 2-\mathrm{N}}\right)$ normalized by biomass weight (higher for the ethanoldosed reactor) were comparable in the two MBBRs, suggesting similar activity in terms of nitrate and nitrite removal in the two biofilms.

\subsubsection{Micropollutant removal kinetics}

Biotransformation kinetics of most of the investigated chemicals could be described with first-order equation (Table 1, process 2), thereby allowing for the estimation of removal rates $\mathrm{k}\left(\mathrm{d}^{-1}\right)$ and pseudo-first order biotransformation rate constants $\mathrm{k}_{\text {bio }}\left(\mathrm{L} \mathrm{g}_{\text {biomass }}{ }^{-1} \mathrm{~d}^{-1}\right)$. Abiotic transformation processes were previously investigated by the authors using plastic (polyethylene) carriers (AnoxKaldnes Z-carriers) and effluent wastewater (Torresi et al., 2016), suggesting no significant impact of abiotic processes (e.g., abiotic hydrolysis, volatilization, sorption onto plastic or glass) on the removal of several targeted micropollutants (Figure S9). Figures 1 and S1 summarize measured and simulated micropollutant concentration profiles during batch experiments. 
The removals of erythromycin, clarithromycin, venlafaxine, carbamazepine, sulfamethoxazole and sulfamethizole was predicted using (i) a pseudo-first order biotransformation model (Table 1, process 2), with no interaction (inhibition/enhancement) between micropollutant and primary substrate; and (ii) additionally, a cometabolic model (Table 1, process 3), assuming that the turnover of the micropollutants is enhanced by the presence of primary substrate. Predictions with the two models are presented in Figure $1 b-d$ using dashed lines and solid lines, respectively. The goodness of the two model fits $\left(\mathrm{R}^{2}\right)$ is summarized in Table S4 (SI). For erythromycin and clarithromycin, the cometabolic model $\left(\mathrm{R}^{2}>0.9\right)$ provided only for a marginal improvement of the fitting compared to the pseudo-first order biotransformation model $\left(\mathrm{R}^{2}>0.8\right)$, making it difficult to draw conclusion on the removal mechanism of these two compounds. However, the prediction of carbamazepine's removal was significantly improved by adopting the cometabolic model $\left(\mathrm{R}^{2}>0.9\right)$ compared to the pseudo first-order biotransformation model $\left(\mathrm{R}^{2}<0.5\right)$ in both MBBRs. Cometabolic biotransformation of carbamazepine has been previously observed in aerobic and anoxic activated sludge (Plósz et al., 2012) with cometabolic biotransformation rate constant qbio (1.2 $\mathrm{L} \mathrm{g}^{-1} \mathrm{~d}^{-1}$ under anoxic condition), in close agreement with our results. Similarly, the removal of venlafaxine, sulfamethoxazole and sulfamethizole removal was better predicted using the cometabolic model $\left(\mathrm{R}^{2}>0.9\right)$. In Figure 1a, the measured and simulated concentration of soluble $\mathrm{COD}(\mathrm{sCOD})$, nitrate $\left(\mathrm{NO}_{3}-\mathrm{N}\right)$ and nitrite $\left(\mathrm{NO}_{2}-\mathrm{N}\right)$ and simulated readily biodegradable $\mathrm{COD}\left(\mathrm{S}_{\mathrm{S}}\right)$ are reported. For the abovementioned micropollutants, $S_{S}$ limitation (approximately after 3 hours from the beginning of the experiment) corresponded to a change in biotransformation kinetics. Interestingly, in the ethanol-fed reactor, the modelled $\mathrm{S}_{\mathrm{S}}$ limitation coincided with a significant decrease in the biotransformation rates of sulfamethoxazole and sulfamethizole (Figure 1d right), thereby leading to a rather low removal rate during the rest of the experiment. A similar effect for both compounds, though at lower extent, was observed for the methanol-dosed reactor. 
Cometabolic transformation of trace chemicals was previously shown in suspended cultures under aerobic, anaerobic and anoxic conditions (Delgadillo-Mirquez et al., 2011; Fernandez-Fontaina et al., 2014; Plósz et al., 2010; Popat and Deshusses, 2011; Tran et al., 2013). Removal via cometabolism was previously observed for sulfamethoxazole in nitrifying (Kassotaki et al., 2016; Müller et al., 2013) and in aerobic and anoxic activated sludge (Alvarino et al., 2016), as well as for erythromycin and roxithromycin (Fernandez-Fontaina et al., 2014) in nitrifying activated sludge. Thus, our results support the hypothesis that the change of primary substrate availability can significantly impact the removal of a number of micropollutants as a result of cometabolic mechanisms under denitrifying conditions.

While the other sulfonamides followed cometabolic biotransformation, the removal of sulfadiazine was different. It could not be described with first-order kinetics $\left(\mathrm{R}^{2}<0.2\right.$ and $<0.4$ for methanoland ethanol-dosed MBBR respectively, dashed lines in Figure $1 \mathrm{e}$ ), due to the presence of its conjugate acetyl-sulfadiazine. Acetyl-sulfadiazine is the main human metabolite of sulfadiazine (Vree et al., 1995) and it has been previously observed to undergo de-acetylation (Zarfl et al., 2009), similarly to other acetyl-sulfonamides such as $\mathrm{N}^{4}$-acetylsulfamethoxazole (Göbel et al., 2007). For these chemicals, a model including retransformation (deconjugation) of acetylsulfadiazine to sulfadiazine and concurrent biotransformation of sulfadiazine was used to estimate biotransformation rate constants $\mathrm{k}_{\mathrm{bio}}$ for sulfadiazine and retransformation rate constant $\mathrm{k}_{\mathrm{Dec}}$ for acetyl-sulfadiazine (Table 1, processes 1 and 2). However, this modelling approach did not adequately describe the concentration changes of sulfadiazine in any of the MBBRs $\left(\mathrm{R}^{2}<0.2\right.$, continuous lines in Figure 1e):

For the methanol-dosed MBBR, acetyl- sulfadiazine was decreasing rapidly and sulfadiazine (being formed from acetyl-sulfadiazine) reached a maximum before being slowly further biotransformed 
354 (Figure 1e left). In the ethanol-dosed MBBR, the acetyl-sulfadiazine was also rapidly removed and 355 sulfadiazine concentration did never increase. Thus, for the ethanol-dosed reactor there is no 356 indication for a deconjugation reaction of acetyl-sulfadiazine to sulfadiazine, while that is partially 357 possible in the methanol-dosed one. Hence, the transformation of acetyl-sulfadiazine probably 358 occurred partially following another metabolic pathway leading to the formation of other 359 (undetected) transformation products. To test whether other pathways could be possible, the 360 EAWAG-BBD pathway prediction systems (EAWAG-BBD, 2016) was used: It showed the 361 possible transformation of acetyl-sulfadiazine to other transformation products, e.g., 2362 aminopyrimidine and 4-aminobenzenesulfonic acid (Figure S6, SI). However, additional research 363 on the different transformation pathways of acetyl-sulfadiazine in the two tested MBBRs is needed 364 to substantiate this hypothesis. Further discussion on the biotransformation of acetyl-sulfadiazine 365 and sulfadiazine in the two investigated MBBRs is reported in S4 in SI.

\subsection{Influence of dosed carbon-source on microbial communities}

We analyzed the biofilm microbial community of the two different MBBRs by 16S rRNA amplicon sequencing. After implementation of quality control measures, a total of 10847 high quality sequences were obtained with an average length of $460 \mathrm{bp}$. Subsequently, the number of reads of each sample was normalized to 4562 sequences and clustered into an average of 690 observed OTUs at $97 \%$ sequence similarity per sample (cut-off level of 3\%). The facultative methanolutilizing $\beta$-Proteobacteria, Methylophilus, was identified as the main relative abundance genus (24\%) in the methanol-dosed reactor (Figure 2) — a result that closely agreed with previous studies on methanol-dosing denitrification systems (Baytshtok et al., 2009; Jenkins et al., 1987; Lu et al., 377 2014). For the biofilm grown in the ethanol-dosed reactor, Arcobacter and Thiothrix genus exhibited $23 \%$ and $9 \%$ relative abundance, respectively. Arcobacter was previously identified in 
full-scale MBBRs treating municipal wastewater (Biswas and Turner, 2012). Thiothrix is known to degrade sulfur containing compounds and it was suggested to influence the removal of sulfa-based antibiotics in membrane bioreactors (Xia et al., 2012). Microbial community diversity in the two MBBRs was evaluated by comparing Shannon diversity and evenness indices. We observed no major difference in the methanol- and ethanol-dosed reactors between Shannon diversity indices $(4.153 \pm 0.05$ and $4.184 \pm 0.03$, mean and standard deviation, respectively) and evenness $(0.092 \pm$ 0.002 and $0.095 \pm 0.001$, respectively) (Figure 2, Table S5 of the SI). Similar values of Shannon diversity indices were found previously in aerobic nitrifying MBBRs (Bassin et al., 2015; Torresi et al., 2016). On the other hand, the extrapolated taxonomic richness ACE in the methanol- and ethanol-dosed reactors were estimated to be $999 \pm 103$ and $781 \pm 87$ OTUs, respectively, thus suggesting slightly differences between the microbial richness of the two biofilms (Figure 2). Similar evidence was obtained from nitrite reductase nirK- and nirS-based restriction fragment length polymorphism (RFLP) analysis on activated sludge supplemented with methanol or ethanol, with higher diversity in terms of richness of nirS genotypes observed in the methanol-dosed sludge (Hallin et al., 2006).

\subsection{Influence of dosed carbon source on micropollutants biotransformation}

A comparative assessment of the estimated $\mathrm{k}_{\mathrm{bio}}$, $\mathrm{q}_{\mathrm{bio}}$ and $\mathrm{k}_{\mathrm{Dec}}$ values for the methanol- and ethanoldosed MBBRs is shown in Figure 3. For 9 compounds the estimated values of biotransformation and cometabolic transformation rate constants $\left(\mathrm{k}_{\mathrm{bio}}\right.$ and $\mathrm{q}_{\mathrm{bio}}$ ) for the methanol-dosed MBBR were higher (1.5 to 2.5 -fold) than those from the ethanol-dosed reactor (namely atenolol, citalopram, trimethoprim, ibuprofen, iopromide, metoprolol, iohexol, iomeprol, sotalol, venlafaxine). Conversely, the sulfonamides acetyl-sulfadiazine, sulfamethoxazole, sulfamethizole were transformed at higher rate constants (up to 2.8-fold) in the ethanol-dosed reactor. The remaining 10 
compounds behaved similarly in both reactors. We further classified the biotransformation potential of the targeted micropollutants of the two denitrifying MBBRs in three groups (Table 3): easily degradable ( $\mathrm{q}_{\text {bio }}$ and $\left.\mathrm{k}_{\text {bio }}>2\right)$, moderately degradable $\left(0.2 \leq \mathrm{k}_{\text {bio }}\right.$ and $\left.\mathrm{q}_{\text {bio }} \geq 2\right)$ and hardly degradable ( $\mathrm{k}_{\mathrm{bio}}$ and $\left.\mathrm{q}_{\mathrm{bio}}<0.2\right)$.

We observed that some of the targeted chemicals classified as easily degradable (propranolol, atenolol, citalopram) presented removal rate constant $\mathrm{k}\left(\mathrm{d}^{-1}\right)$ above $10 \mathrm{~d}^{-1}$ and similar between the two MBBRs (Table 3). As the two MBBRs presented different amount of biomass (Table 2) during batch experiment, the lower values of $\mathrm{k}_{\mathrm{bio}}$ for the high degradable compounds in the ethanol-dosed reactor could mainly derive from the normalization to a higher amount of biomass prevailing in the ethanol-dosed reactor.

On the other hand, a number of moderately degradable chemicals (i.e., X-ray contrast media, ibuprofen, metoprolol and sotalol) were associated to $\mathrm{k}$ and $\mathrm{k}_{\text {bio }}$ values approximately two times higher in the methanol-dosed than in the ethanol-dosed reactor. The two biofilm microbial communities likely played an important role on the biotransformation of these chemicals. As previously described (Section 3.2), the higher microbial richness observed in the biofilm enriched with methanol could have likely contributed to the overall higher micropollutant biotransformation in the methanol-dosed MBBR. Similarly, positive associations between biodiversity and the rates of specific micropollutant biotransformations were observed in activated sludge (Johnson et al., 2015; Stadler and Love, 2016) and MBBR (Torresi et al., 2016).

No major differences were observed between the biotransformation rate constants $\mathrm{k}_{\text {bio }}$ of the hardly degradable compounds (diatrizoic acid, iopamidol, diclofenac and phenazone) in the two MBBRs, suggesting that their removal is neither biomass nor carbon source dependent. 


\subsection{Highlighted compounds}

Among the X-ray contrast media, iopamidol and diatrizoic acid were found to be recalcitrant in both reactors during batch experiment (Figure S1, SI), while iomeprol, iohexol and iopromide were found moderately degradable (Figure 1d). These results are in agreement with previous studies conducted with aerobic MBBRs (Escolà Casas et al., 2015a; Hapeshi et al., 2013). Our results show that denitrifying MBBRs could effectively remove iomeprol, iohexol and iopamidol, with $\mathrm{k}_{\mathrm{bio}}$ comparable to studies on activated sludge (Joss et al., 2006; Onesios et al., 2009)

The analgesic ibuprofen exhibited lower biotransformation rate constants (Table 3) than the ones obtained in previous studies under aerobic conditions (Escolà Casas et al., 2015a,b; Falås et al., 2012; Torresi et al., 2016) as ibuprofen is easily degraded under aerobic conditions. Other analgesics, i.e., phenazone and diclofenac, have also previously observed to be hardly degradable in both aerobic MBBR and activated sludge (Escolà Casas et al., 2015a; Joss et al., 2006). Nevertheless, $\mathrm{k}_{\text {bio }}$ values for diclofenac were reported to be higher under nitrifying conditions in both biofilms and activate sludge (Torresi et al., 2016; Tran et al., 2009) than as obtained in this study under denitrifying conditions, thus indicating limited diclofenac removal under anoxic conditions.

In the batch experiment, citalopram was fully removed in both reactors within 0.4 days (Figure $1 \mathrm{~b}$ ), resulting in a $\mathrm{k}_{\text {bio }}$ of $2.3 \mathrm{~L} \mathrm{~d}^{-1} \mathrm{~g}_{\text {biomass }}^{-1}$ (Table 3). Similar biotransformation kinetics was found in aerobic MBBR (Escolà Casas et al., 2015a) and sludge (Suárez et al., 2012), while anoxic CAS showed lower kientics compared to the one obtained in th anoxic MBBRs of this study. At HRTs higher than 0.4 days, a removal efficiency of $65 \%$ was achieved in a complete autotrophic nitrogen removal process (Alvarino et al., 2015). In our study, predicted removal efficiency of citalopram (at HRT of 0.4 days) was calculated to be $>80 \%$ in both reactors (Equation 1) during continuous-flow 
450

451

452

453

454

455

456

457

operation. Furthermore, in denitrifying activated sludge reactors a $\mathrm{k}_{\text {bio }}$ of $0.5 \mathrm{~L} \mathrm{~d}^{-1} \mathrm{~g}_{\text {biomass }}{ }^{-1}$ was obtained for citalopram (Suárez et al., 2010) and a removal of 44 \% under anoxic condition (Suárez et al., 2010).

The removal of carbamazepine and venlafaxine (with q $\mathrm{q}_{\text {bio }}$ ranging between 1.1 and $1.9 \mathrm{~L} \mathrm{~g}^{-1} \mathrm{~d}^{-1}$ ) followed the kinetics described by the cometabolic model in our study, as suggested previously (see Section 3.1.2). With respect to biotransformation kinetics, only one study showed cometabolic biotransformation rate constants of up to $2 \mathrm{~L} \mathrm{~g}^{-1} \mathrm{~d}^{-1}$ for carbamazepine in aerobic and anoxic activated sludge (Plósz et al., 2012). On the other hand biotransformations rate constants equal to $0.9 \mathrm{~L} \mathrm{~g}^{-1} \mathrm{~d}^{-1}$ in aerobic MBBR have been reported (Escolà Casas et al., 2015a). In our study we thus observed $30 \%$ removal of carbamazepine during batch experiments, which is in agreement with previous studies on MBBR (Escolà Casas et al., 2015a) and activated sludge (Dawas-Massalha et al., 2014; Luo et al., 2014; Zupanc et al., 2013). Thus, low removal of carbamazepine in the tested MBBRs in batch and continuous-flow experiments may be attributed to the limited transformation in the absence of primary substrates.

The biotransformation of the targeted sulfonamides was enhanced in the ethanol-dosed MBBR (up to 1.8 -fold higher). As the ethanol-dosed MBBR showed the highest denitrification rates $\left(\mathrm{r}_{\mathrm{NO} 3,2-\mathrm{N}}\right)$ during the batch experiment, the removal of the targeted sulfonamides may be associated with primary metabolism rather than biofilm composition (i.e., biodiversity). Interestingly, negative correlation between biotransformation kinetics of sulfonamides and biodiversity was also observed in nitrifying MBBRs, and their removal was enhanced at higher nitrification rates in thin biofilms (Torresi et al., 2016). Similarly, the removal of sulfamethoxazole has been previously shown to be dependent on the primary metabolism under anoxic condition in activated sludge, while negligible 
effect of primary substrate was observed under nitrifying condition (Alvarino et al., 2016). This indicates that sulfonamide removal may be influenced by primary metabolism in both nitrifying and denitrifying conditions.

Finally, while $\mathrm{k}_{\mathrm{bio}}$ of clarithromycin and erythromycin was found comparable to studies on aerobic MBBRs (Escolà Casas et al., 2015a), trimethoprim removal occurred with a higher $\mathrm{k}_{\text {bio }}$ under denitrification conditions than in aerobic MBBRs (Escolà Casas et al., 2015a; Falås et al., 2013).

\subsection{Impact of carbon dosing during continuous-flow operation}

A continuous-flow experiment tested different dosing conditions of organic carbon in terms of primary substrate (methanol or ethanol) and influent loading (variable $\mathrm{COD}_{\text {added }} / \mathrm{NO}_{3}-\mathrm{N}_{\text {influent }}$ ratio) without adaptation of the biofilm as described in Section 2.6 (details in Section S7, SI). The removal efficiency of micropollutants did not present any correlation with the tested $\mathrm{COD}_{\text {added }} / \mathrm{NO}_{3^{-}}$ $\mathrm{N}_{\text {influent }}$ ratios and did not significantly differ between the two types of carbon sources (Figure S8, SI). Notably, only trimethoprim removal increased with increasing carbon availability in the ethanol-dosed reactor.

Both MBBR systems exhibited denitrification rates directly proportional to the $\mathrm{COD}_{\text {added }} / \mathrm{NO}_{3^{-}}$ $\mathrm{N}_{\text {influent }}$ ratio (Figure S3, SI). However, at $\mathrm{COD}_{\text {added }} / \mathrm{NO}_{3}-\mathrm{N}_{\text {influent }}$ ratios higher than 4.8 and 3.8 for the methanol- and the ethanol-dosed MBBR, respectively, denitrification rates did not increase and similar effluent concentrations of COD were measured for both MBBRs (estimated to be equal to the inert soluble COD in the influent medium) (Figure S4, SI). This indicates that excess COD dosing during continuous-flow operation could have been used for internal storage rather than as primary energy source. This has been previously observed under substrate feast-famine cycles in 
continuously operated activated sludge (Beun et al., 2000). Similarly, feast-famine conditions associated to change from high to low $\mathrm{COD}_{\text {added }} / \mathrm{NO}_{3}-\mathrm{N}_{\text {influent }}$ ratio during continuous-flow operation might have influenced the performance of the two post-denitrifying MBBRs in this study.

Furthermore, the continuous-flow operation experiment was carried out at HRT of $2 \mathrm{~h}$, simulating HRTs typically operated in denitrification stages in full scale WWTPs, and which might have been too short to observe differences in the removal of micropollutants. In fact, the batch experiment showed that the removal of most of the targeted micropollutants (with the exception of the compounds removed through cometabolism) continued after $2 \mathrm{~h}$ from the start of the experiment

(Figure 1), suggesting a possible removal enhancement at higher HRT. Accordingly, the increase of HRT has been found to enhance the removal of a number of micropollutants in activated sludge (Maurer et al., 2007; Petrie et al., 2014) and MBBR (Mazioti et al., 2015).

\subsection{Comparison of the batch and the continuous-flow experiment}

Figure 4 compares the measured removal efficiencies under continuous -flow operation with the predicted removal efficiencies. The predicted values were calculated using the removal rates $(\mathrm{k})$ estimated in the batch experiment according to first-order kinetics (Table 3). As presented in Figure 4, the removal rates $(\mathrm{k})$ estimated from batch experiments allowed predicting of the elimination of most of the targeted compounds in continuous-flow operation. However, predicted removal efficiencies did not match the measurements for a number of micropollutants, i.e. sulfamethoxazole, carbamazepine, atenolol and trimethoprim. A possible explanation for this discrepancy might be that the removal rates $(\mathrm{k})$ used to predict the removals were obtained by fitting the first order kinetics, while in reality for some compounds cometabolic or deconjugation approaches are more appropriate. 
523 As the biotransformation kinetics of most of the compounds could be described with a first-order

524 equation (Table 1, process 2 and Figure 1), it could be predicted that an HRT of $2 \mathrm{~h}(0.083 \mathrm{~d})$ would only allow a partial removal of the easily biodegradable compounds (e.g., atenolol, trimethoprim and citalopram) in the continuous-flow experiment (Figure 4). For the compounds following this type of biotransformation kinetics, it could be predicted (Equation 1, Section 2.6) that the increase of the HRT up to 6 hours $(0.25 \mathrm{~d})$ would improve the removal efficiency by about $20 \%$, achieving high removals in both reactors $(>70 \%)$ for all the compounds listed as "easily biodegradable" in Table 3.

\section{Conclusions}

In order to investigate the removal of micropollutants in denitrifying Moving Bed Biofilm Reactors (MBBRs), two laboratory-scale MBBRs were tested using nitrified effluent wastewater dosed with methanol and ethanol, respectively. The following conclusions have been drawn:

- According to the batch experiment, all targeted micropollutants showed biotransformation rate constants over $0.2 \mathrm{~L} \mathrm{~d}^{-1} \mathrm{~g}_{\text {biomass }}{ }^{-1}$ under denitrifying condition, except for diclofenac, phenazone, diatrizoic acid and iopamidol, which were found to be recalcitrant. Accordingly, it has been suggested that that HRTs of approximately $6 \mathrm{~h}$ could considerably enhance the removal of most of the targeted micropollutants.

- The biotransformation rate constants in the methanol-dosed MBBR were 1.5 to 2.5-fold higher than in the ethanol-dosed MBBR for 9 out of the 22 spiked pharmaceutical. Oppositely, the sulfonamides acetyl-sulfadiazine, sulfamethoxazole, sulfamethizole were transformed at higher 
biotransformation rate constants in the ethanol-dosed MBBR. The rest of the compounds 547 presented similar biotransformation in both reactors.

- The removal of venlafaxine, carbamazepine, sulfamethoxazole and sulfamethizole was most likely enhanced by the presence of organic growth substrates in the beginning of the batch experiment, suggesting cometabolic removal for these compounds.

- The continuous-flow experiment conducted at conditions typically operated in full-scale 554 WWTPs (i.e., HRT $=2 \mathrm{~h}$ ) did not show significant correlation between the removal efficiency of micropollutants and the increase of carbon dosage or type.

\section{Acknowledgements}

558 This research was supported by (i) the AUFF grant: advanced water purification using bio-inorganic 559 nanocatalysts and soil filters; and (ii) MERMAID: an Initial Training Network funded by the People 560 Programme (Marie-Curie Actions) of the European Union's Seventh Framework Programme 561 FP7/2007-2013/ under REA grant agreement n. 607492. The authors are thankful for technical 562 assistance provided by VA SYD at Sjölunda and Klagshamn (Malmö) wastewater treatment plants. 


\section{References}

Alvarez-Cohen, L., Speitel, G.E., 2001. Kinetics of aerobic cometabolism of chlorinated solvents. Biodegradation 12 (2), 105-126.

Alvarino, T., Nastold, P., Suárez, S., Omil, F., Corvini, P.F.X., Bouju, H., 2016. Role of biotransformation, sorption and mineralization of 14C-labelled sulfamethoxazole under different redox conditions. Science of Total Environment 542, 706-715.

Alvarino, T., Suárez, S., Katsou, E., Vazquez-Padin, J., Lema, J.M., Omil, F., 2015. Removal of PPCPs from the sludge supernatant in a one stage nitritation/anammox process. Water Research. 68, 701-709. d

Anthony, C., 1982. The Biochemistry of Methylotrophs. Academic Press. London

Anthony, C., 2011. How half a century of research was required to understand bacterial growth on $\mathrm{C} 1$ and $\mathrm{C} 2$ compounds; the story of the serine cycle and the ethylmalonyl-CoA pathway. Science. Progress. 94, 109-37.

Bassin, J.P., Abbas, B., Vilela, C.L.S., Kleerebezem, R., Muyzer, G., Rosado, a. S., van Loosdrecht, M.C.M., Dezotti, M., 2015. Tracking the dynamics of heterotrophs and nitrifiers in moving-bed biofilm reactors operated at different $\mathrm{COD} / \mathrm{N}$ ratios. Bioresource Technology $192(3), 131-141$.

Baytshtok, V., Lu, H., Park, H., Kim, S., Yu, R., Chandran, K., 2009. Impact of varying electron donors on the molecular microbial ecology and biokinetics of methylotrophic denitrifying bacteria. Biotechnology and Bioengineering 102 (6), 1527-1536. 
Beun, J.J., Paletta, F., Van Loosdrecht, M.C., Heijnen, J.J., 2000. Stoichiometry and kinetics of poly-beta-hydroxybutyrate metabolism in aerobic, slow growing, activated sludge cultures. Biotechnology and Bioengineering 67 (4), 379-89.

Biswas, K., Turner, S.J., 2012. Microbial community composition and dynamics of moving bed biofilm reactor systems treating municipal sewage. Applied Environmental Microbiology 78 (3), 855-64.

Christensson, M., Lie, E., Welander, T., 1944. A comparison between ethanol and methanol as carbon sources for denitrification. Water Science and Technology 30 (6), 83-90.

Clara, M., Strenn, B., Gans, O., Martinez, E., Kreuzinger, N., Kroiss, H., 2005. Removal of selected pharmaceuticals, fragrances and endocrine disrupting compounds in a membrane bioreactor and conventional wastewater treatment plants. Water Research 39 (19), 4797-807.

Criddle, C.S., 1993. The kinetics of cometabolism. Biotechnology and Bioengineering 41 (11), $1048-56$.

Cumming, G., Fidler, F., Vaux, D.L., 2007. Error bars in experimental biology. Journal of Cell Biology 177 (1), 7-11.

Dawas-Massalha, A., Gur-Reznik, S., Lerman, S., Sabbah, I., Dosoretz, C.G., 2014. Co-metabolic oxidation of pharmaceutical compounds by a nitrifying bacterial enrichment. Bioresource and Technology. 167, 336-42.

Delgadillo-Mirquez, L., Lardon, L., Steyer, J.P., Patureau, D., 2011. A new dynamic model for bioavailability and cometabolism of micropollutants during anaerobic digestion. Water Research 45 (15), 4511-4521. 
606

607

608

609

610

611

612

613

614

615

616

617

618

619

620

621

622

623

624

625

626

Daughton, C.G., Ternes, T.A., 1999. Pharmaceuticals and personal care products in the environment: agents of subtle change? Environmental Health Perspectives. 907-38.

Escolà Casas, M.E., Chhetri, R.K., Ooi, G., Hansen, K.M.S., Litty, K., Christensson, M., Kragelund, C., Andersen, H.R., Bester, K., 2015a. Biodegradation of pharmaceuticals in hospital wastewater by staged Moving Bed Biofilm Reactors (MBBR). Water Research. 83, 293-302.

Escolà Casas, M., Chhetri, R.K., Ooi, G., Hansen, K.M.S., Litty, K., Christensson, M., Kragelund, C., Andersen, H.R., Bester, K., 2015b. Biodegradation of pharmaceuticals in hospital wastewater by a hybrid biofilm and activated sludge system (Hybas). Science of Total Environment. 530-531, 383-392.

Falås, P., Baillon-Dhumez, A, Andersen, H.R., Ledin, A la Cour Jansen, J., 2012. Suspended biofilm carrier and activated sludge removal of acidic pharmaceuticals. Water Research. 46 (4), 1167-75.

Falås, P., Longrée, P., la Cour Jansen, J., Siegrist, H., Hollender, J., Joss, A, 2013. Micropollutant removal by attached and suspended growth in a hybrid biofilm-activated sludge process. Water Research 47 (13), 4498-506.

Fernandez-Fontaina, E., Carballa, M., Omil, F., Lema, J.M., 2014. Modelling cometabolic biotransformation of organic micropollutants in nitrifying reactors. Water Research 65C, 371383.

Fischer, K., Majewsky, M., 2014. Cometabolic degradation of organic wastewater micropollutants by activated sludge and sludge-inherent microorganisms. Applied Microbiology and 
628

629 630

Göbel, A., McArdell, C.S., Joss, A., Siegrist, H., Giger, W., 2007. Fate of sulfonamides, macrolides, and trimethoprim in different wastewater treatment technologies. Science of Total Environment 372 (2-3), 361-371.

Hagman, M., Nielsen, J.L., Nielsen, P.H., La, J., Jansen, C., 2007. Mixed carbon sources for nitrate reduction in activated sludge-identification of bacteria and process activity studies. Water Environmen Research 42, 1539-1546

Hallin, S., Throbäck, I.N., Dicksved, J., Pell, M., 2006. Metabolic profiles and genetic diversity of denitrifying communities in activated sludge after addition of methanol or ethanol. Applied Microbiology and Biotechnology 72 (8), 5445-52.

Hapeshi, E., Lambrianides, A., Koutsoftas, P., Kastanos, E., Michael, C., Fatta-Kassinos, D., 2013. Investigating the fate of iodinated X-ray contrast media iohexol and diatrizoate during microbial degradation in an MBBR system treating urban wastewater. Environmental Science and Pollution Research 20 (6), 3592-606.

Hiatt, W.C., Grady, C.P.L., 2008. An Updated Process Model for Carbon Oxidation, Nitrification, and Denitrification. Water Environmen Research 80 (11), 2145-2156.

Hill, M., 1973. Diversity and evenness: a unifying notation and its consequences. Ecology 54 (2), 427-432.

Jenkins, O., Byrom, D., Jones, D., 1987. Methylophilus - a New Genus of Methanol-Utilizing Bacteria. International Journal of Systematic Bacteriology. 37 (4), 446-448. 
Johnson, D.R., Helbling, D.E., Lee, T.K., Park, J., Fenner, K., Kohler, H.P.E., Ackermann, M., 2015. Association of biodiversity with the rates of micropollutant biotransformations among full-scale wastewater treatment plant communities. Applied and Environmental Microbiology $81(2), 666-675$.

Joss, A., Siegrist, H., Ternes, T.A., 2008. Are we about to upgrade wastewater treatment for removing organic micropollutants? Water Science and Technology 57, 251-5.

Joss, A., Zabczynski, S., Göbel, A., Hoffmann, B., Löffler, D., McArdell, C.S., Ternes, T. a., Thomsen, A., Siegrist, H., 2006. Biological degradation of pharmaceuticals in municipal wastewater treatment: Proposing a classification scheme. Water Research 40 (8), 1686-1696.

Kassotaki, E., Buttiglieri, G., Ferrando-Climent, L., Rodriguez-Roda, I., Pijuan, M., 2016. Enhanced sulfamethoxazole degradation through ammonia oxidizing bacteria co-metabolism and fate of transformation products. Water Research.

Liu, L., Binning, P.J., Smets, B.F., 2015. Evaluating alternate biokinetic models for trace pollutant cometabolism. Environmental Science and Technology 49 (4), 2230-2236.

Louzeiro, N., 2002. Methanol-induced biological nutrient removal kinetics in a full-scale sequencing batch reactor. Water Research. 36 (11), 2721-2732.

Lu, H., Chandran, K., Stensel, D., 2014. Microbial ecology of denitrification in biological wastewater treatment. Water Research. 64, 237-254.

Luo, Y., Guo, W., Ngo, H.H., Nghiem, L.D., Hai, F.I., Kang, J., Xia, S., Zhang, Z., Price, W.E., 2014. Removal and fate of micropollutants in a sponge-based moving bed bioreactor. Bioresource Technology 159, 311-9. 
Maurer, M., Escher, B.I., Richle, P., Schaffner, C., Alder, a C., 2007. Elimination of beta-blockers in sewage treatment plants. Water Research. 41 (7), 1614-22.

Mazioti, A. a., Stasinakis, A.S., Pantazi, Y., Andersen, H.R., 2015. Biodegradation of benzotriazoles and hydroxy-benzothiazole in wastewater by activated sludge and moving bed biofilm reactor systems. Bioresource Technology 192, 627-635.

Mokhayeri, Y., Riffat, R., Murthy, S., Bailey, W., Takacs, I., Bott, C., 2009. Balancing yield, kinetics and cost for three external carbon sources used for suspended growth postdenitrification. Water Science and Technology 60, 2485-91.

Müller, E., Schüssler, W., Horn, H., Lemmer, H., 2013. Aerobic biodegradation of the sulfonamide antibiotic sulfamethoxazole by activated sludge applied as co-substrate and sole carbon and nitrogen source. Chemosphere 92, 969-78.

Onesios, K.M., Yu, J.T., Bouwer, E.J., 2009. Biodegradation and removal of pharmaceuticals and personal care products in treatment systems: a review. Biodegradation 20 (4), 441-466.

Pan, Y., Ni, B.-J., Lu, H., Chandran, K., Richardson, D., Yuan, Z., 2015. Evaluating two concepts for the modelling of intermediates accumulation during biological denitrification in wastewater treatment. Water Research. 71, 21-31.

Petrie, B., McAdam, E.J., Lester, J.N., Cartmell, E., 2014. Assessing potential modifications to the activated sludge process to improve simultaneous removal of a diverse range of micropollutants. Water Research, 180-92.

Plósz, B.G., Benedetti, L., Daigger, G.T., Langford, K.H., Larsen, H.F., Monteith, H., Ort, C., Seth, R., Steyer, J.-P., Vanrolleghem, P. a, 2013. Modelling micro-pollutant fate in wastewater 
collection and treatment systems: status and challenges. Water Science and Technology 67, 115.

Plósz, B.G., Langford, K.H., Thomas, K. V, 2012. An activated sludge modeling framework for xenobiotic trace chemicals (ASM-X): assessment of diclofenac and carbamazepine. Biotechnology and Bioengineering 109 (11), 2757-69.

Plósz, B.G., Leknes, H., Thomas, K. V, 2010. Impacts of competitive inhibition, parent compound formation and partitioning behavior on the removal of antibiotics in municipal wastewater treatment. Environmental Science and Technology 44 (2), 734-42.

Polesel, F., Andersen, H.R., Trapp, S., Plosz, B.G., 2016. Removal of antibiotics in biological wastewater treatment systems - A critical assessment using the Activated Sludge Modelling framework for Xenobiotics (ASM-X). Environmental Science and Technology 50 (19), 10316-10334

Popat, S.C., Deshusses, M.A., 2011. Kinetics and inhibition of reductive dechlorination of trichloroethene, cis-1,2-dichloroethene and vinyl chloride in a continuously fed anaerobic biofilm reactor. Environmental Science and Technology 45 (84), 1569-1578.

Reichert, P., 1994. Aquasim - a tool for simulation and data-analysis of aquatic systems. Water Science and Technology 30 (2), $21-30$.

Rittmann, B.E., 1992. Microbiological detoxification of hazardous organic contaminants: the crucial role of substrate interactions. Water Science and Technology 25, 403-410.

Roeleveld, P.J., Van Loosdrecht, M.C.M., 2002. Experience with guidelines for wastewater characterisation in The Netherlands. Water Science and Technology 45 (6), 77-87. 
Santos, S.G., Zaiat, M., Varesche, M.B., Foresti, E., 2001. Comparative research on the use of methanol, ethanol and methane as electron donors for denitrification. Environmental Engineering Science 21 (39), 313-320.

Sözen, S., Çokgör, E.U., Orhon, D., Henze, M., 1998. Respirometric analysis of activated sludge behaviour-II. Heterotrophic growth under aerobic and anoxic conditions. Water Research. 32, $476-488$.

Stadler, L.B., Love, N.G., 2016. Impact of microbial physiology and microbial community structure on pharmaceutical fate driven by dissolved oxygen concentration in nitrifying bioreactors. Water Research. 104, 189-199.

Su, L., Aga, D., Chandran, K., Khunjar, W.O., 2015. Factors impacting biotransformation kinetics of trace organic compounds in lab-scale activated sludge systems performing nitrification and denitrification. Journal Hazardaus Material 282, 116-24.

Suárez, S., Lema, J.M., Omil, F., 2010. Removal of Pharmaceutical and Personal Care Products ( PPCPs ) under nitrifying and denitrifying conditions. Water Research 44 (10), 3214-3224.

Suárez, S., Ramil, M., Omil, F., Lema, J.M., 2005. Removal of pharmaceutically active compounds in nitrifying-denitrifying plants. Water Science and Technology 52 (8), 9-14.

Suárez, S., Reif, R., Lema, J.M., Omil, F., 2012. Mass balance of pharmaceutical and personal care products in a pilot-scale single-sludge system: influence of T, SRT and recirculation ratio. Chemosphere 89 (2), 164-71.

Torresi, E., Fowler, J.S., Polesel, F., Bester, K., Andersen, H.R., Smets, B.F., Plosz, B.G., Christensson, M., 2016. Biofilm thickness influences biodiversity in nitrifying MBBRs - 

Implications on micropollutant removal. Environmental Science and Technology. 50 (17), 9279-9288

Tran, N.H., Urase, T., Kusakabe, O., 2009. The characteristics of enriched nitrifier culture in the degradation of selected pharmaceutically active compounds. Journal of Hazardous Material 171 (1-3), 1051-7.

Tran, N.H., Urase, T., Ngo, H.H., Hu, J., Ong, S.L., 2013. Insight into metabolic and cometabolic activities of autotrophic and heterotrophic microorganisms in the biodegradation of emerging trace organic contaminants. Bioresource Technology. 146, 721-31.

Vree, T.B., de Ven, E.S. van, Verwey-van Wissen, C.P.W.G.M., Baars, A.M., Swolfs, A., van Galen, P.M., Amatdjais-Groenen, H., 1995. Isolation, identification and determination of sulfadiazine and its hydroxy metabolites and conjugates from man and Rhesus monkey by high-performance liquid chromatography. Journal of Chromatography B: Biomedical Sciences and Applications 670 (1), 111-123.

Wittebolle, L., Marzorati, M., Clement, L., Balloi, A., Daffonchio, D., Heylen, K., De Vos, P., Verstraete, W., Boon, N., 2009. Initial community evenness favours functionality under selective stress. Nature 458 (72238), 623-6.

Xia, S., Jia, R., Feng, F., Xie, K., Li, H., Jing, D., Xu, X., 2012. Effect of solids retention time on antibiotics removal performance and microbial communities in an A/O-MBR process. Bioresource Technology. 106, 36-43.

Zarfl, C., Klasmeier, J., Matthies, M., 2009. A conceptual model describing the fate of sulfadiazine and its metabolites observed in manure-amended soils. Chemosphere 77 (6), 720-726. 
752 Zupanc, M., Kosjek, T., Petkovšek, M., Dular, M., Kompare, B., Širok, B., Blažeka, Ž., Heath, E., 753 2013. Removal of pharmaceuticals from wastewater by biological processes, hydrodynamic 754 cavitation and UV treatment. Ultrason. Sonochem. 20, 1104-12.

\section{Web references}

759 EAWAG-BBD Pathway Prediction System. http://eawag-bbd.ethz.ch/predict/index.html (Accessed $760 \quad$ February 24, 2016). (2016) 
Table 2. Values of denitrification rates normalized by carriers surface area $\left(\mathrm{r}_{\mathrm{NO}, 2-\mathrm{N}}\right)$ and biomass concentration $\left(\mathrm{k}_{\mathrm{NO} 3,2-\mathrm{N}}\right)$ measured during batch experiments. SA: total surface area of carriers in the MBBRs.

\begin{tabular}{ccccc}
\hline MBBR & $\begin{array}{c}\text { SA } \\
\left(\mathrm{m}^{2}\right)\end{array}$ & $\begin{array}{c}\text { Biomass } \\
\left(\mathrm{g} \mathrm{L}^{-1}\right)\end{array}$ & $\begin{array}{c}\mathbf{r}_{\mathrm{NO} 3,2}-\mathbf{N} \\
\left(\mathrm{gNO}_{3,2}-\mathrm{N} \mathrm{m}^{-2} \mathrm{~d}^{-1}\right)\end{array}$ & $\begin{array}{c}\mathbf{k}_{\mathrm{NO} 3,2}-\mathbf{N} \\
\left(\mathrm{gNO}_{3,2}-\mathrm{N} \mathrm{g}_{\text {biomass }}{ }^{-1} \mathrm{~d}^{-1}\right)\end{array}$ \\
\hline Methanol-dosed & 0.2 & $3.28 \pm 0.93$ & $1.77 \pm 0.92$ & $0.11 \pm 0.06$ \\
Ethanol-dosed & 0.2 & $4.20 \pm 0.25$ & $2.32 \pm 0.62$ & $0.11 \pm 0.03$ \\
\hline
\end{tabular}

779

780 
Table 3. Values of $k, k_{b i o}, q_{b i o}$ and $k_{\text {Dec }}$ estimated for the two MBBRs from the data obtained in the batch experiments. " $k$ " defines the removal rate constant obtained following single first-order kinetics and not accounting for biomass concentration and sorption processes. " $k_{b i o}$ " and " $q_{b i o}$ " refer to removal rate constants normalized for biomass and sorption processes. Unindexed values correspond to " $k_{\text {bio" }}$ (Biotransformation process, Table 1, Process 2). Index (1) indicates the case of retransformation rate constant " $k_{\text {Dec }}$ " of acetyl-sulfadiazine to sulfadiazine (Transformation process, Table 1, Process 1). Index (2) refers to the cometabolic rate constant " $q_{b i o "}$ (Cometabolism, Table 1, Process 3). The following abbreviations are used: n.d. = not degradable, SD =standard deviation.

\section{Methanol-dosed MBBR}

Compound
$\mathrm{k} \pm \mathrm{SD}$
$\mathrm{k}_{\mathrm{bio}}, \mathrm{q}_{\mathrm{bio}} \pm \mathrm{SD}$

$\left(d^{-1}\right)$
$\left(\mathrm{L} \mathrm{d}^{-1} \mathrm{~g}_{\text {biomass }}{ }^{-1}\right)$

\section{Ethanol-dosed MBBR}

$\mathrm{k} \pm \mathrm{SD}$

$\left(\mathrm{d}^{-1}\right)$

$\mathrm{k}_{\text {bio }}, \mathrm{q}_{\mathrm{bio}} \pm \mathrm{SD}$

Easily degradable; $\boldsymbol{k}_{\text {bio }}, \boldsymbol{q}_{\text {bio }}>2$

\begin{tabular}{ccccc}
\hline Propranolol & $17.8 \pm 0.2$ & $12.9 \pm 1.3$ & $17.7 \pm 0.2$ & $11.7 \pm 0.7$ \\
\hline Atenolol & $17.8 \pm 0.2$ & $6.4 \pm 0.6$ & $17.6 \pm 0.2$ & $5.1 \pm 0.3$ \\
\hline Citalopram & $14.2 \pm 0.9$ & $4.3 \pm 0.5$ & $12.3 \pm 0.1$ & $2.3 \pm 0.1$ \\
\hline Trimethoprim & $13.6 \pm 0.1$ & $4.1 \pm 0.4$ & $9.0 \pm 0.1$ & $2.1 \pm 0.1$ \\
\hline Acetyl-sulfadiazine & $12.1 \pm 0.3$ & $3.7 \pm 0.4^{(1)}$ & $17.6 \pm 0.2$ & $4.2 \pm 0.3^{(1)}$ \\
\hline
\end{tabular}

Moderately degradable; $0.2 \leq k_{b i o}, q_{b i o} \leq 2$

\begin{tabular}{|c|c|c|c|c|}
\hline Ibuprofen & $4.6 \pm 0.1$ & $1.4 \pm 0.4$ & $2.3 \pm 0.1$ & $0.5 \pm 0.03$ \\
\hline Clarithromycin & $2.9 \pm 0.7$ & $\begin{array}{l}1.0 \pm 0.2^{(2)} \\
0.6 \pm 0.1\end{array}$ & $4.4 \pm 0.9$ & $\begin{array}{l}0.9 \pm 0.2^{(2)} \\
0.4 \pm 0.1\end{array}$ \\
\hline Iopromide & $3.0 \pm 0.1$ & $0.9 \pm 0.1$ & $1.7 \pm 0.1$ & $0.4 \pm 0.1$ \\
\hline Metoprolol & $2.6 \pm 0.1$ & $0.8 \pm 0.2$ & $1.7 \pm 0.1$ & $0.4 \pm 0.03$ \\
\hline Iohexol & $2.3 \pm 0.1$ & $0.7 \pm 0.2$ & $1.2 \pm 0.1$ & $0.3 \pm 0.1$ \\
\hline lomeprol & $2.1 \pm 0.1$ & $0.6 \pm 0.1$ & $1.2 \pm 0.1$ & $0.3 \pm 0.1$ \\
\hline Sotalol & $1.3 \pm 0.1$ & $0.5 \pm 0.1$ & $0.7 \pm 0.1$ & $0.2 \pm 0.02$ \\
\hline Erythromycin & $1.5 \pm 0.1$ & $\begin{array}{l}0.5 \pm 0.1^{(2)} \\
0.2 \pm 0.1\end{array}$ & $2.5 \pm 0.1$ & $\begin{array}{l}0.6 \pm 0.1^{(2)} \\
0.2 \pm 0.1\end{array}$ \\
\hline Venlafaxine & $6.0 \pm 0.1$ & $\begin{array}{l}1.9 \pm 0.2^{(2)} \\
0.1 \pm 0.1\end{array}$ & $4.8 \pm 0.1$ & $\begin{array}{l}1.1 \pm 0.1^{(2)} \\
0.1 \pm 0.1\end{array}$ \\
\hline Carbamazepine & $3.9 \pm 0.1$ & $\begin{array}{l}1.2 \pm 0.3^{(2)} \\
0.1 \pm 0.1\end{array}$ & $4.6 \pm 0.1$ & $\begin{array}{l}1.1 \pm 0.1^{(2)} \\
0.1 \pm 0.1\end{array}$ \\
\hline Sulfamethoxazole & $5.6 \pm 0.8$ & $\begin{array}{l}1.7 \pm 0.2^{(2)} \\
0.1 \pm 0.1\end{array}$ & $13.5 \pm 0.7$ & $\begin{array}{l}3.2 \pm 0.2^{(2)} \\
0.1 \pm 0.1\end{array}$ \\
\hline Sulfamethizole & $5.8 \pm 0.9$ & $\begin{array}{l}1.8 \pm 0.2^{(2)} \\
0.1 \pm 0.1\end{array}$ & $13.8 \pm 0.8$ & $\begin{array}{c}3.3 \pm 0.2^{(2)} \\
0\end{array}$ \\
\hline Sulfadiazine & $1.9 \pm 0.2$ & $0.6 \pm 0.1$ & $4.2 \pm 0.6$ & $1.0 \pm 0.2$ \\
\hline
\end{tabular}

Hardly or non-degradable; $k_{b i o}, q_{b i o}<0.2$

\begin{tabular}{ccccc}
\hline Diatrizoic acid & $0.3 \pm 0.1$ & $0.1 \pm 0.02$ & $0.1 \pm 0.1$ & $0.1 \pm 0.1$ \\
\hline lopamidol & $0.2 \pm 0.1$ & $0.1 \pm 0.02$ & $0.1 \pm 0.1$ & $0.1 \pm 0.1$ \\
\hline Diclofenac & n.d. & n.d. & n.d. & n.d. \\
\hline Phenazone & n.d. & n.d. & n.d. & n.d.
\end{tabular}



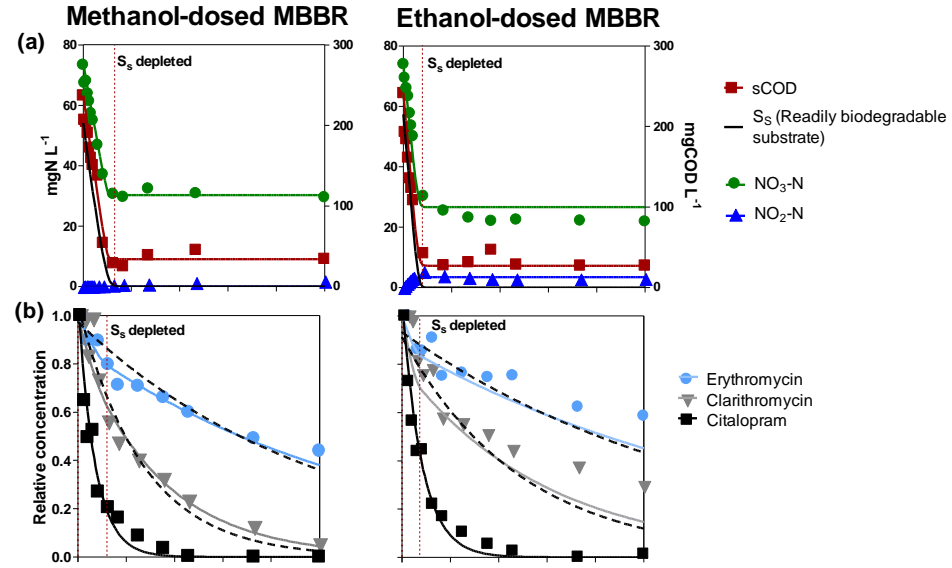

- Erythromycin

F. Clarithromycin
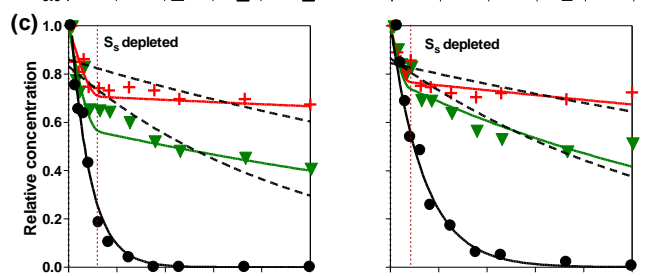

$\checkmark$ Venlafaxine

+ Carbamazepin
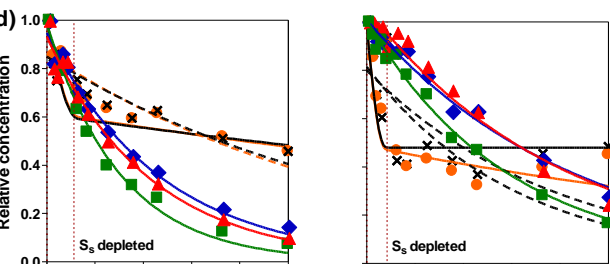

- Sulfamethoxazole

* Sulfamethizole

lomeprol

tohexol
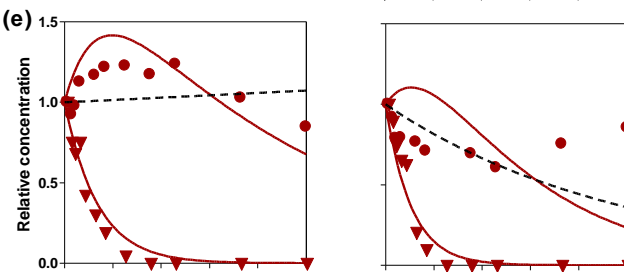

\section{- Sulfadiazine}
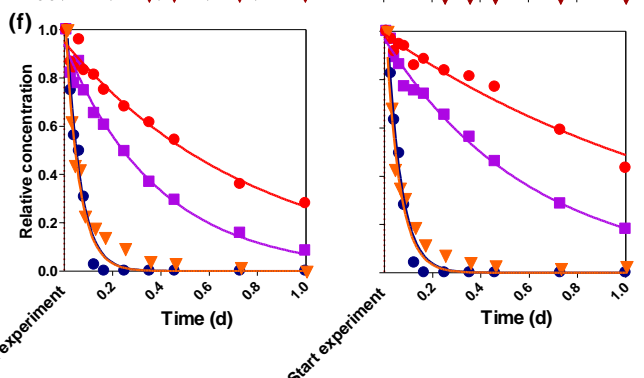

- Metopro

- Propranolo

- Atenolol

Figure 1. Batch experiment results for selected compounds. On the X-axes "Time (d)" designates the sampling time-points. On the Y-axes "Relative concentration" refers to concentrations normalized to the measured starting concentrations. Symbols refer to measurements while lines refer to modelling. [a] Macro-pollutants. Readily biodegradable substrate $\left(\mathrm{S}_{\mathrm{S}}\right)$ is only modelled. [b-d] Solid lines: modelled concentrations assuming cometabolism (process 3, Table 1). Dashed lines: concentrations according to the biotransformation model (process 2, Table 1). [e] Solid lines: biotransformation-retransformation model (process 1, Table 1) assuming deconjugation of acetyl-sulfadiazine to sulfadiazine. Dashed lines: biotransformation model (process 2, Table 1),. [f] Solid lines: concentrations according to the biotransformation model (process 2, Table 1). 


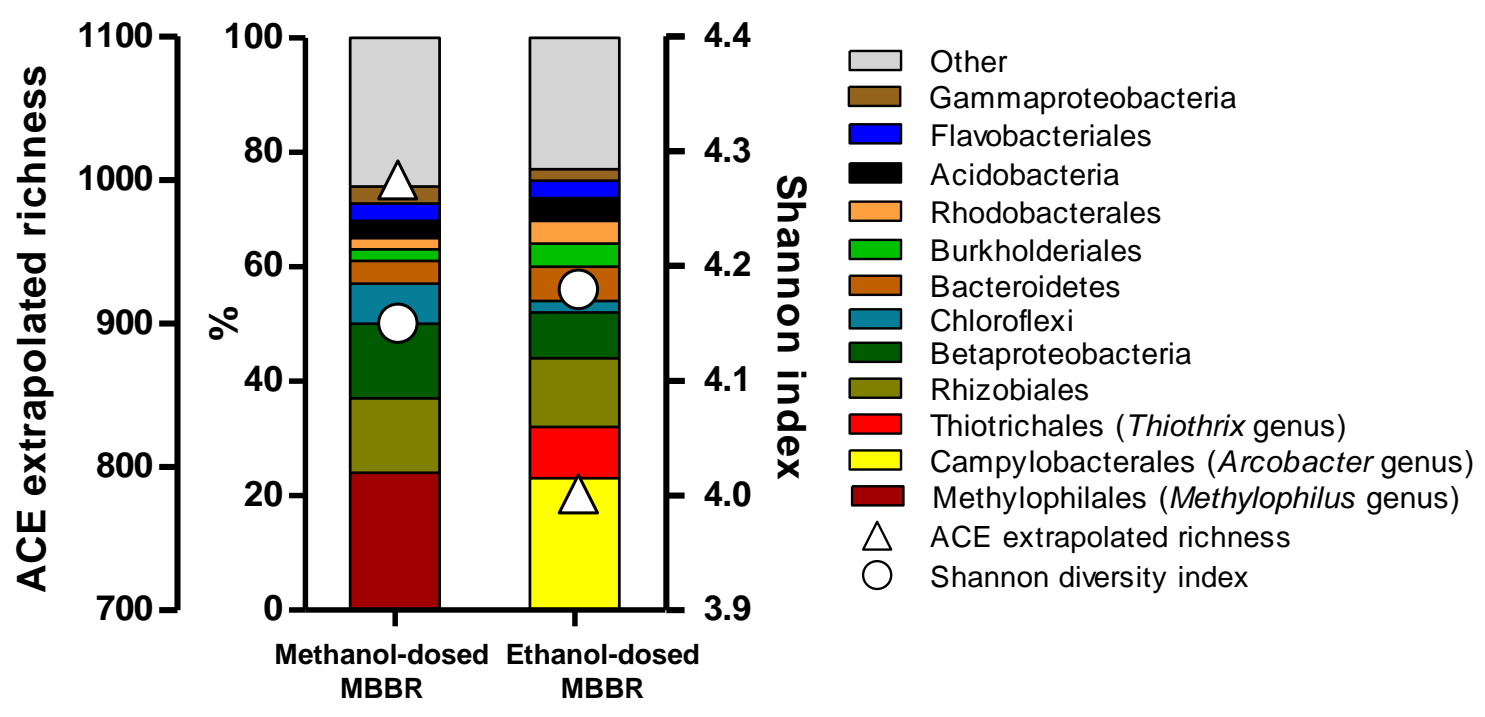

804 Figure 2. Order-level taxonomic classification of 16S rRNA amplicons of the two MBBRs. The three most abundant orders are reported also at genus level (Methylophiulus, Arcobacter and Thiotrix). Taxa abundance is expressed in percentage (second left axis). Alpha-diversity is measured as ACE extrapolated richness (first left axis) and Shannon diversity index (right axis). 

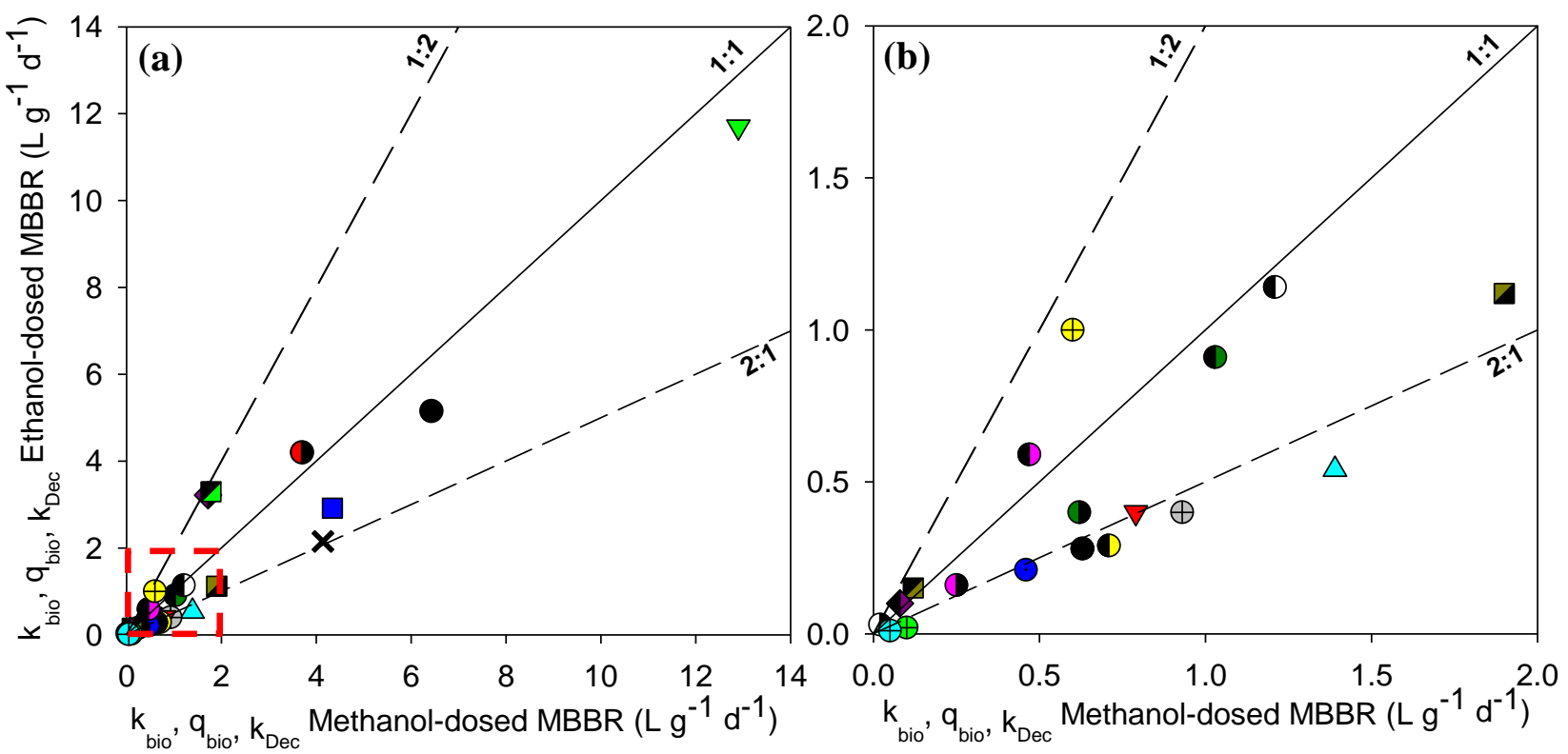

Figure 3. Comparative assessment between methanol-dosed reactor ( $x$-axes) and the ethanol-dosed reactor ( $y$-axes) of the removal kinetics $k_{b i o}, q_{b i o}$ and $k_{\text {Dec }}$ estimated for all targeted compounds (a) and for compounds with biokinetics ranging between 0 and $2 \mathrm{~L} \mathrm{~g}_{\text {biomass }}{ }^{-1} \mathrm{~d}^{-1}$ (b). Dashed lines $(2: 1$ and 1:2) delimit area where biokinetics are $\mathbf{2}$-folder higher or lower than other estimated values. In the legend, when not specified, symbols refer to estimated $k_{\text {bio. }}$. 

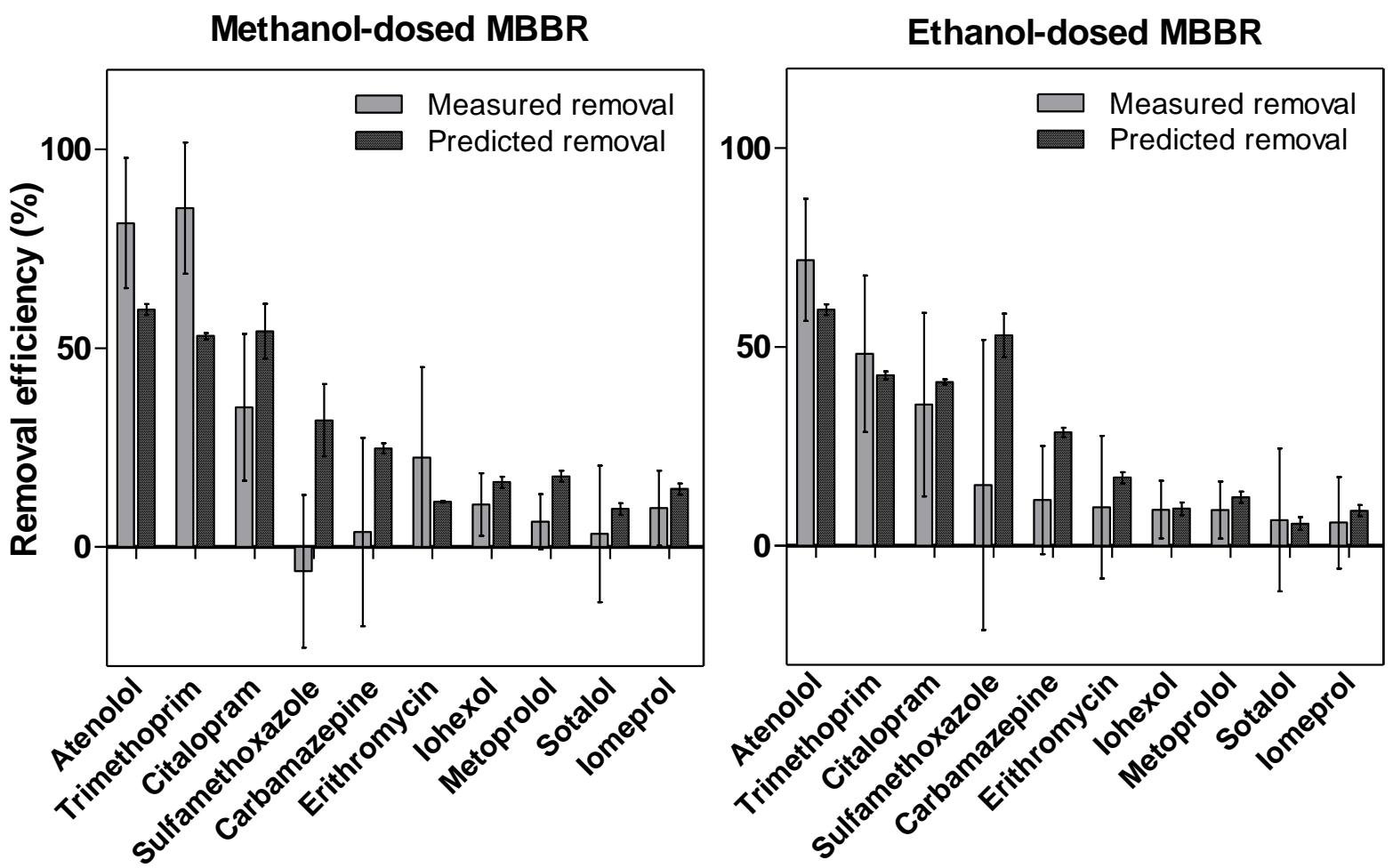

Figure 4. Measured mean removal efficiency of micropollutants of all the tested $\mathrm{COD}_{\mathrm{added}} / \mathrm{NO}^{3}-\mathrm{N}$ influent ratios (presented in Table S3, SI) during the whole continuous-flow experiment, taking into account that no correlation was found between micropollutant removal and $C^{2} D_{\text {added }} / N^{3}-N^{3}$ influent ratios. The measured removals were calculated as difference between influent and effluent concentration, expressed as a percentage. Predicted removal was based on removal rate constants $k$ $\left(d^{-1}\right)$ derived from batch experiments, calculated according to Equation 1 in Section 2.6. 